\title{
The Implementation of the Profiled Pedagogical Class Model in the Framework of Continuous Teacher Education
}

\author{
Anna O. Budarina \\ Institute of Education \\ Immanuel Kant Baltic Federal University \\ Kaliningrad, Russia \\ ABudarina@kantiana.ru
}

\author{
Alexandra S. Zelko \\ Immanuel Kant Baltic Federal University \\ Kaliningrad, Russia
}

\author{
Tatiana P. Mishurovskaya \\ Municipal Autonomous Educational Institution the Yu.A. Gagarin Gymnasium No. 40 \\ Kaliningrad, Russia \\ mougimn40@gmail.com
}

\begin{abstract}
The study presents the results of the model implementation of the profiled pedagogical class in high school as a part of the experiment of professional pedagogical education enhancement within the framework of continuous teacher education in the Kaliningrad region. The curriculum for profiled classes, models for curriculum design for student teachers in the system of higher pedagogical education, and the strategic sessions for teacher trainers in the context of lifelong learning are proposed. The assessment of the results of the project is conducted in integrative ways in order to test the multiple abilities and skills of future teachers. The results make it possible to conclude that the proposed model can be successfully replicated and implemented in the context of pedagogically oriented education for schoolchildren as well as a part of professional skills development of teacher trainers.
\end{abstract}

Keywords: pedagogical class, continuous pedagogical education, professional skills development, student teachers, teacher trainers, pedagogically oriented education, profiled school

\section{INTRODUCTION}

The decade 2018-2027 has been announced to become the Decade of Childhood in Russia. In his opening remarks, the Chairman of the Government of the Russian Federation Dmitry Medvedev, during the governmental meeting "On the plan of the main events within the framework of the Decade of Childhood," noted that "children should be given the opportunity to learn something other than the school curriculum and develop their abilities. It is important for children to receive practical and versatile education, and to try themselves in different areas, immerse themselves in the profession ... " [1].
Profiled education for schoolchildren becomes relevant not only for the school, but also for all interested educational organizations. So, in Kaliningrad in 2018 at the Immanuel Kant Baltic Federal University (IKBFU), a structural unit "Center for the Development of Modern Competencies of Children" was established [2]. The aim of the Center is to create special conditions for improving the quality of education of children and youth with the following measures:

- the implementation of additional educational programs for children and youth and training for the development of modern competencies [3];

- the establishment of a network form of interaction with educational organizations of the region when creating conditions for continuous education [4].

The center is designed to solve the following tasks:

1. The development of modern competencies among the general population, including students and teachers of educational organizations of general [5], professional and additional education [6] through the provision of educational services using modern methods and technologies for the development of modern competencies.

2. Development and maintenance of promising practices, models, methods, technologies and educational programs for the development of competencies, with the participation of and in cooperation with international and national companies and stakeholders. 


\section{MethodS}

Current challenges and issues demand a systematic and multifaceted work, which could not but concern primarily the specialized institutes in the system of higher education. Within the framework of the project described above, the Distributed Pedagogical Class Model called 'the Teacher of the Future' is functioning at the Institute of Education at the IKBFU [7]. The pedagogical class is a pedagogically oriented and socially active community of students in grades 9 to 11 of different schools of the Kaliningrad region, aged 15-18, united by a common interest, goals and desire to learn the profession of the teacher in practice, as a rule, with subsequent admission to higher educational institutions for BA programs of pedagogical areas of training.

The general goal of establishing such a class is the implementation of vocational guidance for high school students and their introduction to professional culture through an additional (university) part of profiled education with the implementation of an individual curriculum at the request of the student.

The project aims at teaching the basics of the profession, conditioning soft competences (including the development of critical thinking, leadership, teamwork, creativity, communication skills, etc.), understanding the requirements and challenges of 'the vision of the future' and 'professions of the future' $[8 ; 9 ; 10 ; 11]$. During the training, high school students master the skills and the activities of a volunteer and an assistant counselor for schools and recreational camps [12; $13 ; 14 ; 15]$.

According to the results of the project, contracts on hold are envisaged, as well as the referral to target places in pedagogical areas of training and additional points for the admission to the IKBFU. The main (school) part of education is provided by the school within the framework of profiled, pedagogical education in high school.

The expected results of the program are the formation of students' interest in the teaching profession and motivation to implement their own projects in the field of education [16], as well as the willingness of young people to share their experience and best practices at the regional, national [17] and international levels.

The total duration of the program is 2 years (an advanced course), the total number of academic hours per year is 144 . The specific features of the contingent are a permanent composition with the possible participation of students with special educational needs.

The peculiarities of the organization of the educational process include its various forms. This is both traditional and integrative via the organization of training through the network interaction with resource centers of the IKBFU [7]. The Institute of Education has 15 resource centers in the areas of teacher education, early vocational guidance, selfdetermination and professional counseling, the implementation of psycholinguistic models of intensive teaching methods, the implementation of STEAM practices in teaching and further education, psychological and pedagogical education, the implementation of interactive methods training, etc. They constitute the part of the practical module of the program for students to obtain the necessary professional skills.

The program develops professional competencies in a wide range: in the field of mentoring, cross-cultural communication, mediation strategies, special and corrective pedagogy, inclusive education, practical skills in the implementation of cross-platform technologies and digital learning environment.

Schoolchildren are included into all social and volunteer projects of the Institute of Education at the IKBFU [6]. The Institute actively runs the Laboratory called 'the Project Incubator', which, in particular, implements the regional project 'School of Counselors' together with the Agency for Youth Affairs of the Kaliningrad Region and the Kaliningrad Regional Branch of the Russian Student Detachments [14]. Since 2008, the School of Counselors annually trains more than 100 initiative young people from all over the region, which gives them the right to work as counselors in regional, national and international health camps and centers.

Modern case-methods, micro-teaching, professional identity training, simulation techniques for creating digital learning environment [18; 19], educational quests and professional diagnostics are actively used in the program.

\section{RESULTS}

The integration of teachers of the Kaliningrad region into the system of advanced professional training via the format of a strategic session has become a reality of the regional educational environment and integrated regional social and educational ecosystem.

In the context of developing a strategy for the development of the education system of the Russian Federation, presented by the national project 'Education' [20], the program for the development of education of the Russian Federation for 20182025 , the development strategy of each educational organization, the emphasis is made on training specialists who are able to predict the prospects for the development of educational systems for years to come. This emphasis has shifted from the search for answers to the challenges of the time strategies for the formation of school management teams.

It is especially important to hold strategic sessions when a new educational institution is about to be launched, when a new team is formed, which will become the main condition and guarantee of the success of the complex of innovations that determine the place of a new school in the municipal and regional educational spaces of the functioning ecosystem. A competent approach to organizing strategic sessions in preparation for the opening of a new school allows creating conditions for updating, adjusting, modernizing the regional and municipal education systems as a whole.

In December 2018, the Ministry of Education of the Kaliningrad Region and the IKBFU initiated a pilot project called 'I-school' to develop the concept of a brand-new Kaliningrad school No. 57 to begin the first academic year on September 1, 2019. The project program provided for a series 
competition between regional educational systems, and in the future rating systems are considered by us as a significant argument in favor of consolidating the format of the strategic session as advanced training forms on the basis of existing school-resource centers.

\section{DISCUSSION}

In the result of the implementation of the profiled pedagogical class model in the framework of continuous teacher education in the region we have got the following outcomes.

1. The University becomes an integrator of updating the personnel potential of the region.

The Institute of Education in the structure of the university is seen as a result of responding to the situation in the region (the construction of new schools, the process of enlargement (association) of educational organizations, etc.). The national project, the project "Teacher of the Future" has determined the creation and development of a network of resource centers "Pedagogical Education" $[13 ; 20]$, their role in the development of new forms of social partnership and models for training professional personnel for the education system of the Kaliningrad region is inevitably important.

2. The regional ecosystem of the University and the resource centres are testing innovative models of continuing education for education leaders $[13 ; 21]$ (such as "The Club of the Modern Principal", "The Association of Young Teachers", training future teachers from among students of the IKBFU).

3. The organization of strategic sessions as a form and model of interaction between social partners in the interests of developing human resources help to solve important social problems (such as launching a new large school as a center of social culture and modern education [22]).

At present, the developed program is being tested, taking into account the experience of training the teaching staff taking into account the world, national and regional practices. The successful implementation of the program will be indicated by an increase in the number of applicants for pedagogical fields of training, as well as the general level of training of students.

\section{ACKNOWLEDGMENT}

This research was financially supported by the Immanuel Kant Baltic Federal University and Russian Academic Excellence Project 5-100.

\section{REFERENCES}

[1] O plane osnovnykh meropriyatiy v ramkakh Desyatiletiya detstva [On the Plan of the Main Activities within the Framework of the Decade of Childhood] [Electronic resource]. Available at: http://government.ru/news/33171 (Accessed: 15 September 2019) (in Russian).

[2] O tsentre [About the Centre] [Electronic resource]. Available at: http://unichild.kantiana.ru/?page_id=64 (Accessed: 20 August 2019) (in Russian). 
[13] Aprobatsii novoy modeli attestatsii uchiteley [New testing model of teachers] [Electronic resource]. Available at: https://edu.gov39.ru/?ELEMENT_ID=16694 (Accessed: 15 August 2019) (in Russian). obrazovaniya v professional'nyh obrazovatel'nyh organizaciyah i vuzah", Voprosy obrazovaniya, 2019, vol. 1, pp. 181-214.

[4] E. F. Zeer, V. S. Tret'yakova, and V. I. Miroshnichenko, "Strategicheskie orientiry podgotovki pedagogicheskih kadrov dlya sistemy nepreryvnogo professional'nogo obrazovaniya", Obrazovanie i nauka, 2019, vol. 6, pp. 93-121.

[5] R. S. Nagovitsyn, E. G. Zamolotskikh, I. I. Potashova, and L. V. Rybakova, "Model of the system of raising the social status of the teacher in the region on the basis of a pedagogical university", European journal of contemporary education, 2019, vol. 8, pp. 315-327 (Accessed: 15 September 2019).

[6] P. A. Kislyakov, E. A. Shmeleva, and O. Govin, "Sovremennoe volonterstvo $\mathrm{v}$ vospitanii prosocial'nogo povedeniya lichnosti", Obrazovanie i nauka, 2019, vol. 6, pp. 122-146.

[7] Proyekt "Zvezda Budushchego" [The project "The Star of the Future"] [Electronic resource]. Available at: https://gov39.ru/news/101/133327/ (Accessed: 15 September 2019) (in Russian).

[8] "The Atlas of Emerging Jobs" [Electronic resource]. Available at: http://www.skolkovo.ru/public/media/documents/research/sedec/SKOL KOVO_SEDeC_Atlas_2.0_Eng.pdf (Accessed: 15 September 2019) (in Russian).

[9] J. Field, "Lifelong Learning", International Encyclopedia of Education (Third Edition), 2010 [Electronic resource]. Available at: https://www.sciencedirect.com/referencework/9780080448947/internati onal-encyclopedia-of-education (Accessed: 15 September 2019).

[10] J. Halliday "Lifelong Learning", International Encyclopedia of Education, (Third Edition), 2010 [Electronic resource]. Available at: https://www.sciencedirect.com/referencework/9780080448947/internati onal-encyclopedia-of-education (Accessed: 15 September 2019).

[11] O. V. Rogach, E. V. Frolova, and T. M. Ryabova, "Trajectories of buildings a career of a teacher within academic competition", European journal of contemporary education, 2019, vol. 8, pp. 338-347.

[12] A. O. Budarina, A. S. Zelko, and O. V. Parakhina, "Uchitel' budushchego: rabochaya tetrad'. Chast' pervaya", Kaliningrad: Izd-vo BFU im. I. Kanta [The Teacher of the future: Workbook. Part one]. Kaliningrad: Publishing House of I. Kant Baltic Federal University, 2018, 44 p. (in Russian).

[14] The Agency for Strategic Initiatives "Available at: https://asi.ru/eng/about_agency/ (Accessed: 15 September 2019) (in Russian).

[15] K. V. Pavlenko, K. N. Polivanova, A. A. Bochaver, and E. V. Sivak, "Dopolnitel'noe obrazovaniya shkol'nikov: funkcii, roditel'skie strategii, ozhidamye rezul'taty", Voprosy obrazovaniya, 2019, vol. 2, pp. 241261.

[16] Proyekt "Povysheniye urovnya finansovoy gramotnosti naseleniya i razvitiya finansovogo obrazovaniya $\mathrm{v}$ Rossiyskoy Federatsii" [The project "Financial literacy and financial education in the Russian Federation"] [Electronic resource]. Available at: https://vashifinancy.ru/upload/medialibrary/Obzor_O_proekte.pdf (Accessed: 15 September 2019) (in Russian).

[17] Professional'nyy standart pedagoga [The national professional standards of teachers] [Electronic resource]. Available at: http://fgosvo.ru/docs/101/69/2 (Accessed: 15 September 2019)

[18] Pilotnyy proyekt "Tsifrovaya shkola" [The pilot project "Digital school"] [Electronic resource]. Available at: https://tass.ru/obschestvo/4978524 (Accessed: 15 September 2019) (in Russian).

[19] O. K. Krokinskaya, "Obrazovanie postindustrial'noj epohi: nastrojka na individa i intellekt", Vysshee obrazovanie v Rossii, 2019, vol. 7, pp. 2942.

[20] Natsional'nyy proyekt "Obrazovaniye" [The national project "Education"] [Electronic resource]. Available at: https://edu.gov.ru/national-project/ (Accessed: 13 August 2019) (in Russian).

[21] I. N. Emel'yanova, O. A. Teplyakova, and G. Z. Efimova, "Praktika ispol'zovaniya sovremennyh metodov ocenki na raznyh stupenyah obrazovaniya", Obrazovanie i nauka, 2019, vol. 6, pp. 9-28.

[22] G. Fischer, "Lifelong Learning and its Support with New Media", Cultural Concerns International Encyclopedia of the Social and Behavioral Sciences, 2001 [Electronic resource]. Available at: https://www.sciencedirect.com/referencework/9780080448947/internati onal-encyclopedia-of-education (Accessed: 15 September 2019). 